LAERE MIDDEL ODK

\title{
A systematic review of research on how students and teachers use didactic learning materials in L1
}

By Stig Toke Gissel and Bettina Buch

Korrekt citering af denne artikel efter APA-systemet (American Psychological Association System, 7th Edition): Gissel, S. T. \& Buch, B. (2020).

A systematic review of research on how students and teachers use didactic learning materials in L1. Learning Tech - Tidsskrift for læremidler, didaktik og teknologi, (7), 90-129. DOI 10.7146/lt.v5i7.117281 


\section{Abstract}

Denne artikel præsenterer resultaterne af et systematisk forskningsreview om, hvordan elever og lærere i grundskolen bruger didaktiske læremidler i modersmålsundervisningen. Didaktiske læremidler er læringsressourcer, der er skabt med henblik på undervisning og læring. Vi inkluderer både digitale og analoge læremidler og metodisk forskelligartet forskning publiceret mellem 2008-2018. Målene med reviewet er at skabe overblik over 1) hvor meget forsknin,g der er på dette felt, 2) hvilke aspekter af brug der undersøges, 3 ) hvad forskningen kan fortælle os om brugen af didaktiske læremidler og 4) hvordan forskningen blev udført metodisk. Vi syntetiserer de inkluderede studier i seks temaer, som beskriver grene af fælles forskningsinteresser artiklerne imellem. Sidst foreslår vi en forskningsagenda, som vi mener kan bringe feltet, forskning i brugen af læremidler, fremad.

This article presents the results of a systematic review of research of how students and teachers in primary and lower secondary school use didactic learning materials in L1 (mother tongue education). Didactic learning materials are learning resources made for the purposes of teaching and learning. We include both digital and analogue learning resources and methodically diverse research published in 2008-2018. The aims of the review are mapping 1) how much research there is in this field, 2) which aspects of use are investigated, 3) what the research can tell us about the use of didactic learning materials, and 4) how the research was conducted methodically. We synthesize the included studies into six themes that describe strands of research interests. Finally, we will propose a research agenda for moving the field of research in the use of didactic learning materials forward. 


\section{A systematic review of research on how students and teachers use didactic learning materials in L1}

\section{Background}

Didactic learning materials are produced for the purposes of teaching and learning (Hansen \& Gissel, 2017). Usually, didactic materials have a built-in didactic approach, that is, the producer interprets the curriculum or subject and the learning material embodies this interpretation. Typically, the material has explicit aims, student tasks, and measures for evaluation. Examples include a textbook for a specific subject and grade level or a course for a specific topic within a school subject. Furthermore, didactic materials often have explicit guides to teachers (and often students) as to how they are to be used, that is, a description of the intended learning design. This makes it especially interesting for studying the interrelation between teacher/student and intended learning design and how users use and perceive these learning resources. To the extent that teachers use the learning materials as prescribed, didactic learning materials can have a great impact in transforming the intended curriculum into a taught and learned curriculum (Schubert, n.d.). However, to some extent teachers should make active choices and adaptations to make the learning material fit students' needs and dispositions.

Mappings suggest that didactic learning materials, digital or analogue, are still used extensively as a basis for instruction by teachers. For example, according to the Trends in International Mathematics and Science Study (TIMSS) 2011, 75\% of primary school teachers in 4 th grade and $77 \%$ of teachers in 8 th grade base their instruction on a mathematics (Mullis, Martin, Foy, \& Arora, 2012). Various mappings of Norwegian teachers' use of textbooks show the textbook tends to play a significant role 
in classroom instruction across subjects (Gilje, 2016). Sikorová (2011) reported on textbook use in a study conducted in lower secondary schools in the Czech Republic. One hundred and fifty-five lessons were observed across 20 classes to determine the prevalence of textbook use in various phases of the lessons and the time and frequency of textbook-based activities. It was found that textbooks were used extensively for presenting new content, either by students reading textbook texts aloud or following the text accompanied by the teacher's explanation. Students, however, rarely used the textbook for their homework activities. Sigurgeirsson (1992) reported great variance across subjects in percentage of teaching time spent with textbook-based activities in Iceland, with geography teachers using textbooks nearly all the time and music teachers rather scarcely (16\%).

Watt (2015) reviewed US research on the curriculum role and use of textbooks and found quantitative studies showing textbooks to be dominant in teaching as well as great teacher dependency on textbooks. This is confirmed in several international studies concerning the influence of learning materials on teacher practices and teaching in classes (Houang \& Schmidt, 2008; Sosniak \& Perlman, 1990; Valverde, Bianchi, Wolfe, Schmidt, Houang, \& Study, 2002). Valverde et al. (2002) concluded that textbooks are one of the most important elements in the teaching in schools. Sosniak and Perlmann (1990) and Schmidt, McKnight, Houang, Wang, Wiley, Cogan, and Wolfe (2001) described a significant relationship between content and classroom teaching. In a Scandinavian context, Gilje, Ingulfsen, Dolonen, Furberg, Rasmusse, Klug, Knain, Mørch, Naalsund, and Skarpaas (2016) found that learning materials greatly influence the teaching taking place in the classroom. However, Watt (2015) also identified qualitative case studies that show that teachers vary in their use of textbooks and do not use them with fidelity. Teachers do not automatically follow the instructions and the progression in their textbooks. Also, the same teachers can have different patterns of textbook use across subjects. Similarly, Sikorová and Červenková (2014) identified four styles of teacher textbook use.

Hence, the research interest in mapping textbook use and studying the use at close range seems no less relevant today. However, previous literature reviews have indicated that research addressing the use of learning materials by teachers and students is sparse. A review edited by Knudsen (2011) of research on learning resources in the Nordic countries and five other 
European countries (totaling 11 countries) between 2000-2011 showed that textbooks (i.e., didactic learning materials) were by far the most prevalent focus of research. Furthermore, it was found that research on learning materials was primarily preoccupied with analysing learning resources, such as texts, with a primary focus on content and secondarily on form. The use of these resources by students and teachers was rarely studied. Methodical observations in classrooms and interviews were seldom included in these studies. The aspect of use was rarely investigated empirically and was found to be present mostly as hypothetical reflections based on analysis of content and form. Wikman and Horsley (2012, p. 45) compared textbook research conducted in Finland and Australia and found that in the area of "research analyzing activities in classrooms also including the use of educational aids" there were too few findings and hence excluded it from their review.

As can be seen, there are few studies investigating the use of learning materials in classrooms and there is a need for an overview covering the use of learning materials as it pertains to how these materials are used, the extent to which this use has been studied, and which methods have been used. In this article, we present the results of a systematic review of research of how students and teachers in primary and lower secondary school use didactic learning materials. ${ }^{1}$

\section{Our research questions are as follows:}

- What can international research tell us about teachers' and students' use of didactic learning materials in L1?

- How much research is there on this topic?

— How has this research been conducted (research design and methods)?

- Which aspects of use were investigated and how can these studies shed light on other aspects of learning materials, that is, design, context, and determining outcome?

1 The authors wish to thank: Emil Back Olsen, who participated in retrieving research articles and helped screen the search results; the research librarian at UCL University College, Anne-Marie Fiala Carlsen, who helped us carry out the database searches; Morten Olesen who assisted in generating search strings. 
It follows that the aim of the review is configurative, that is, the review is trying to understand a field of research and provide new insights through identifying (new) ways of studying this field (Gough, Thomas, \& Oliver, 2012). Even though our research questions are broad, that is, the review is methodologically inclusive and includes all research topics that fall within the inclusion criteria, we limit ourselves to focus only on research that is about (but not limited to) L1, mother tongue language teaching.

In the following sections, we will present our method for performing the review, that is, inclusion and exclusion criteria and search strategy. Furthermore, we will define the key concepts in the review and discuss how they can be operationalized. Then we present our results and discuss implications for future reviews and other research.

\section{Method}

We intended to perform a systematic review, that is, a review with clear and accountable methods (Gough et al., 2012). Hence, we performed block searches wherever possible, provided full transparency of all search strings in the various databases used (Appendix 1), and defined clear criteria for inclusion and exclusion. Furthermore, we chose to avoid snowballing or other measures to find relevant publications beyond the search results. Essentially, this is a trade-off between the transparency of the method and the volume of relevant publications identified.

\section{Databases}

We searched the following international databases: Education Resources Information Center (ERIC), Teacher Reference Center (TRC), PsycINFO, and Academic Search Premier (ASP). The review is carried out in relation to two projects, "Praxis interpretations of learning materials" (PaL) and "Quality in Nordic Teaching” (QUINT), which study the use of learning materials in Denmark and the Nordic countries, respectively. Hence, to increase the chances of finding relevant research from a Nordic context, we supplemented the international search with the following Nordic databases: Den danske forskningsdatabase (The Danish research database), Oria.no (Norwegian search engine for academic libraries), and LIBRIS (search engine of the National Library of Sweden). The Nordic databases allow block search to 
varying degrees and have different limitations vis-à-vis searches. Hence, we had to develop tailored search strings (including search terms in the relevant languages) for these searches. The full search strings of all databases used arepresented in Appendix 1.

\section{Inclusion and Exclusion Criteria}

In this review, the interest is in any research about teachers' and students' use of didactic learning materials in L1. Hence, we include classroom research, research about the use of learning materials and teacher planning, that is, any teaching/learning activity that involves didactic learning materials. The review includes both digital and analogue learning resources and methodically diverse research. In order to be included the research had to study the actual use of learning materials, not just mention it, theorize about it, or infer it.

\section{Figure 1.}

List of exclusion and inclusion criteria.

\begin{tabular}{|c|c|}
\hline Focus 1 & $\begin{array}{l}\text { Classroom research, use of learning materials, teacher } \\
\text { planning, that is, any teaching/learning activity that involves } \\
\text { didactic learning materials. }\end{array}$ \\
\hline Focus 2 & Included research must study use of learning materials. \\
\hline Subject & Mother tongue (L1) education and/or learning. \\
\hline Language of publications & English and Nordic. \\
\hline Grade level & Primary and/or lower secondary school. \\
\hline Type & $\begin{array}{l}\text { - Peer reviewed research publications } \\
\text { - including reviews, literature studies and meta-analyses. } \\
\text { - Both qualitative and quantitative studies. }\end{array}$ \\
\hline Time span & January 2008-July 2018. \\
\hline Excluded & Studies that solely focus on remedial education. \\
\hline
\end{tabular}

Looking at the full list of our inclusion criteria (Figure 1), there are some limitations of the study since we include only papers published in English and Nordic languages. This means that the review has not identified international research published in other languages than the aforementioned. Also, since our interest is elementary school education and current research, we only include peer-reviewed research about L1 education in primary 
and/or lower secondary school between January 2008 and July 2018.

\section{Search Strings and Blocks}

We searched the thesauri of the international databases ERIC, TRC, PsycInfo, and ASP for relevant indexed terms. However, we chose to use quotes to group words into specific phrases instead of using the indexed terms. This means that papers that have not yet been indexed are included. Furthermore, all four databases can be searched simultaneously, and duplicates are removed automatically. However, it is necessary to perform searches with phrases in both singular and plural to ensure that every relevant occurrence of the word is identified.

The search was performed using three blocks containing phrases for L1, type of learning material and grade level, as well as an exclusion block with phrases for second and foreign language teaching (see full search strings in Appendix 1).

In the following sections, we briefly reflect on the complexity of defining search words for the 'L1' and 'learning material' blocks and why we could not reach a viable definition of 'use'.

L1

Ongstad (2012) pointed out that delineating mother tongue education or $\mathrm{L} 1$ is difficult for several reasons. In some contexts, the child's preferred or first language is used as a term (for example, 'mother tongue'). Alternatively, and extensively, mother tongue education is connected to the nation or state, for example in the term 'L1' that refers to the preferred majority language; this introduces some complexity in multistate countries with different educational systems and in countries without a unique language corresponding to the country's name (Ongstad, 2012). Furthermore, viewing L1 or the mother tongue subject as a unity that contains certain sub-disciplines is in itself an interpretation that might not accurately reflect historical developments and capture international tendencies (Ongstad, 2012). To capture this complexity, we chose to use a variation of relevant terms in English that should cover the range of synonyms for L1.

\section{Learning Material}

Identifying studies about didactic learning materials, that is, materials produced for the purposes of teaching and learning (Hansen \& Gissel, 2017), requires a broad search strategy. 
Internationally, there is no common terminology for characterizing this subgroup of learning resources. 'Instructional materials', 'educational resources', 'textbooks' and 'learning modules' are all relevant indexed terms in the international databases. We chose to add 'digital' to the phrases and we also took steps to capture teacher-developed learning materials. We supplemented the indexed terms with a host of other terms hoping to capture as many relevant articles as possible.

\section{Use: The Missing Block}

Use in this review encompasses anything that teachers or students might do with didactic learning materials or their thoughts about their use. We did not find a feasible way to define the focus on use. We initially had a block with terms such as 'use', 'teaching, 'teacher praxis', 'praxis', 'planning', and 'teaching methods'. However, this created noise in the search since no articles were excluded. Searching without a block defining use, on the other hand, inevitably included many articles not relevant for the review, which had to be excluded in the manual reviewing process.

\section{Records and Manual Screening}

Searches were performed Friday, November 02, 2018. As expected, our search yielded many hits: a total of 1.136 records after removal of internal duplicates (Figure 2). In addition, we expected to exclude many records in the abstract screening process. A total of 1.065 records were excluded at this step, leaving only 71 articles for full-text assessment. The reasons for exclusion in the full-text assessment are reported in Table 1. After the fulltext assessment, in which we took a closer look at studies that potentially could be about use of didactic learning materials even though the abstract did not state this explicitly, we were left with 18 records for the synthesis.

To conclude on the research question of how much research there is on student and/or teacher use of didactic learning materials in L1, the answer is: There is extensive research on learning resources, but rather few of these studies actually study use. 


\section{Figure 2.}

Number of hits from each of the databases and the total number of hits after removal of internal duplicates, records screened and excluded, number of records assessed in fulltext and number of studies included.

\section{Records identified through database searching}

International databases

- Education Resources Information Center (ERIC): 340

- Teacher Reference Center (TRC): 57

- PsycINFO: 35

- Academic Search Premier: 121

\section{Nordic databases}

- Den danske forskningsdatabase: 393

- Oria no: 73

- Libris: 192

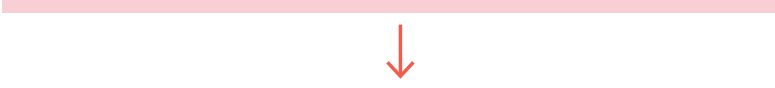

Records after duplicates removed $(n=1.136)$

Records excluded $(n=1.065)$

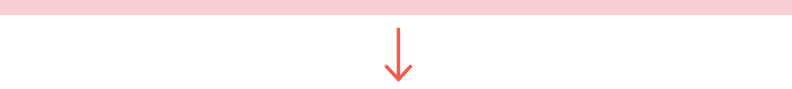

Records screened $(n=1.136)$

Full-text articles excluded, with reasons $(n=53)$

Full-text articles assessed for eligibility $(n=71)$

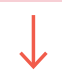

Studies included in synthesis $(n=18)$ 
Table 1.

Reasons for exclusion in the full-text

assessment and number of excluded records

for each reason.

\begin{tabular}{|c|c|}
\hline Reason for exclusion & Number of excluded records \\
\hline Does not study use of learning material & 11 \\
\hline Not about didactic learning material & 20 \\
\hline Not L1 & 6 \\
\hline Not primary and/or lower secondary school & 2 \\
\hline $\begin{array}{l}\text { Not research (for example inspirational material for teachers, } \\
\text { tools for evaluating learning resources or anecdotal essays) }\end{array}$ & 7 \\
\hline Conference abstract that was not retrievable & 7 \\
\hline Total & 53 \\
\hline
\end{tabular}

\section{The Included Studies}

For the purposes of transparency in reporting the results of the review, we list the included studies and give them each a number to easily identify them in the sections to come. Full references can be found in the references section.

\#1: Burkhauser, M. A., \& Lesaux, N. K. (2007). Exercising a bounded autonomy: Novice and experienced teachers' adaptions to curriculum materials in an age of accountability.

\#2: Eilam, B., \& Poyas, Y. (2012). Teachers' interpretations of texts-image juxtapositions in textbooks: From the concrete to the abstract.

\#3: Erixon, P. (2014). On the remediation, relativisation and reflexivity of mother tongue education.

\#4: Fälth, L. (2013). The use of interventions for promoting reading development among struggling readers.

\#5: Flanagan, S., \& Shoffer, M. (2013). Teaching with(out) technology: Secondary English teachers and classroom technology use.

\#6: Gallagher, H. A., Arshan, N., \& Woodworth, K. (2016). Impact evaluation of the National Writing Project's College-Ready Writing Project in high poverty rural districts.

\#7: Gissel, S. T. (2015). Scaffoldings students' independent decoding of unfamiliar text with prototype of an ebook-feature.

\#8: Grossman, P., \& Thompson, C. (2008). Learning from curriculum materials: Scaffolds for new teachers?

\#9: Hanghøj, T., Hautopp, H., Jessen, C., \& Christoffersen,

R. D. (2014). Redesigning and reframing educational scenarios for Minecraft within mother tongue education.

\#10: Kitson, L. (2011). Reconceptualising understandings of texts, readers and contexts: One English teacher's response to using multimodal texts and interactive whiteboards. 
\#11: Lenski, S., Larson, M., McElhone, D., Davis, D. S., Lauritzen,

C., Villagómez, Yeigh, M., Landon-Hays, M., LeJeune, M., \& Scales,

W. D. (2006). What teachers want: A state-wide survey of reading and English language arts teachers' instructional materials, preferences, and practices.

\#12: Lorenz, B., Green, T., \& Brown, A. (2009). Using multimedia graphic organizer software in the prewriting activities of primary school students: What are the benefits?

\#13: McElvany, N., Schroeder, S., Baumert, J., Schnotz,

W., Horz, H., \& Ullrich, M. (2012). Cognitively demanding learning materials with texts and instructional pictures: teachers' diagnostic skills, pedagogical beliefs and motivation.

\#14: Merchant, H. H. (2010). 3D virtual worlds as environments for literacy learning.

\#15: Moran, C. (2018). “Just don’t bore us to death”: Seventh graders' perceptions of flipping a technology-mediated English language arts unit.

\#16: Renita, S. (2008). Really reading: What does Accelerated Reader teach adults and children?

\#17: Savage, R. S., Erten, O., Abrami, P., Hipps, G., Comaskey, E., \& van Lierop, D. (2010). ABRACADABRA in the hands of teachers: The effectiveness of a web-based literacy intervention in grade 1 language arts programs.

\#18: Warren, S. J., Stein, R. A., Dondlinger, M. J., \& Barab,

S. A. (2009). A look inside a MUVE design process: Blending instructional design and game principles to target writing skills.

\section{Results}

In the following sections, we report:

— which entities (teachers, students, both teachers and students or other entities) are the focus of study in the included articles,

— which study designs (qualitative, quantitative or mixed methods) are used,

- which countries the studies originate from,

— which areas of L1 the studies address.

Of the eighteen studies, eight focused on both students and teachers (studies $\# 3, \# 4, \# 6, \# 12, \# 13, \# 14, \# 16, \# 17$ ), seven focused exclusively on teachers (studies $\# 1, \# 2, \# 7, \# 8, \# 9, \# 10, \# 11$ ) three exclusively on students (studies $\# 7, \# 15, \# 18$ ). Hence, the use of didactic learning materials in $\mathrm{L} 1$ is seldom studied without focusing on the teacher as a factor in their use.

The included studies were, for the most part, qualitative (11 studies $\# 1, \# 2, \# 3, \# 5, \# 8, \# 9, \# 10, \# 12, \# 14, \# 16, \# 18)$; six studies 


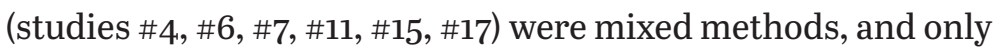
one study (\#13) was solely quantitative. Nine studies originated in the USA, two studies were carried out in Sweden, and two in Denmark. Australia, Germany, UK, Canada, and Israel were represented by one study each.

Four studies were (solely or primarily) about reading (studies $\# 4, \# 7, \# 10, \# 11)$. Four studies were solely about production of texts (studies $\# 6, \# 9, \# 12, \# 18$ ) and two studies were about interpretation of fiction (studies \#4 and \#15), while one study (\#8) was about both writing of texts and interpretation. Three studies were about literacy in general (studies \#1, \#14, and \#17) and two studies (studies \#3 and \#5) were not intervention studies, and therefore the researchers dealt with whatever fields of the L1 subject were taught in the classes observed. One study (\#13) did not specify which areas of L1 were in focus.

\section{Synthesis}

There are three fundamental perspectives on studying learning materials (Bundsgaard \& Hansen, 2011) (Figure 3):

\section{Figure 3.}

The three perspectives on studying didactic learning materials.

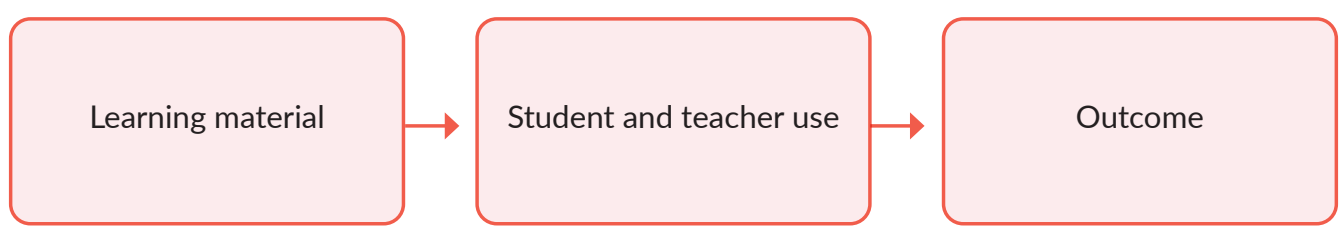

Learning material: the potential learning potential. When the potential learning potential of a learning resource is studied, the focus is on the learning material as a text. The analysis of the design and content of the learning material allows identification of the potential for learning in the learning resource, but it is only speculative because this potential has to be actualized by teachers and students.

Student and teacher use: actualized learning potential. When teachers and students use learning materials, part of the poten- 
tial learning potential will be actualized in the design for learning. A design for learning is a teacher's orchestration of social processes (using learning materials) to facilitate the learning of students as well as what students actively do to create meaning (Selander \& Kress, 2010). Using didacticized learning materials, the teacher will optimally make didactical choices to transform the learning material into a design for learning. For example, the teacher can either use the material as suggested in the teacher's guide or adapt or redidactizise the learning material (Hansen, 2006), that is, make didactical choices to transform the learning material into a design for learning.

Outcome: Realized learning potential. From the third perspective, the outcome of the actualized learning potential is determined. Studies interested in outcome can determine this in many ways, for example, by determining effect estimates (by measuring learning outcomes, motivation, etc.), by observing outcomes as behavioural patterns (for example, students writing longer or better text, participating in more meaningful dialogue about literary texts), or by mapping experienced outcomes from participants in the study (by conducting interviews or surveys, for example, on their experience with using a learning resource for the purposes of learning).

In our review, we searched for studies addressing actualized learning potential. Hence, in our coding of the articles we were interested in what the studies could tell us about use of the learning materials. We also excluded studies that only focused on the learning material as text and/or outcome without in some way studying actualized learning potential. However, we realized that in the identified studies about use of learning materials, many of the studies actually contributed interesting insights about the relation between the study of use and two other perspectives: the learning material as text and the outcome of using the learning material.

In our synthesis here we organize the included studies into six themes that characterize the research interest of the studies and the perspectives that can be drawn from these studies. The six themes are:

— Agents using (and negotiating, perceiving, socially constructing) learning resources 
- Mapping use to monitor implementation vs. mapping use to give teachers a voice

- Use as an outcome

- Context matters in the study of use

— The study of use has implications for the design of learning materials

— The study of use has implications for determining the outcome of learning materials

In the first two of our six themes, Agents using (and negotiating, perceiving, socially constructing) learning resources and Mapping use to monitor implementation vs. mapping use to give teachers a voice, the focus is exclusively on use. In the third theme, Use as an outcome, use is studied as the outcome of an intervention. The fourth theme, Context matters in the study of use, reminds us that the study of use can benefit from embracing a wider context (i.e., looking beyond the confines of the classroom). In the last two perspectives, The study of use has implications for the design of learning materials and The study of use has implications for determining the outcome of learning materials, the studies show that studying use of didactic learning materials has consequences for the design of learning resources (the learning material as text) and the study of outcome (realized learning potential), respectively. Each study can be grouped under more than one theme.

Not all themes are weighted equally since there are an unequal number of studies included in each theme, and the concluding remarks can be of different lengths and weights.

\section{Studies Organized into Six Themes}

\section{Theme 1: Agents using (and negotiating, perceiving, socially constructing) learning resources}

This group of studies is characterized by a shared research interest. They ask: How do actors perceive, socially construct, negotiate, or make meaning of learning materials and the broader tendencies the learning materials are examples of? The focus is on understanding and exploring complex subjective and social phenomena, that is, human behaviour, through the perspectives of actors. Hence, the epistemological position is hermeneutical or phenomenological. Ontologically, these studies adopt a constructionist position, that is, that social phenomena and catego- 
ries are produced through social interaction and are constantly revised (Bryman, 2012, p. 33).

Articles placed under this theme are studies $\# 2, \# 3, \# 5, \# 9$, $\# 10$, \#13 and \#14.

Merchant (2010) is prototypical of this theme. The research question of the study was: When teachers use digital learning materials in which they can create a $3 \mathrm{D}$-universe and the aim is to strengthen students' literacy, what definitions of literacy and literacy-actions do teachers adopt? The primary interest of the study was in teachers' perceptions and the design processes of the design team that created the learning resource, and the teachers' adaptation of it through their design processes. The research design was qualitative. It was an inductive and explorative case-study using classroom observations, field notes of teachers' planning processes, and analysis of chat logs discussing the learning material, supplemented by interviews with both teachers and students and teacher questionnaires. This study was also theory-based, drawing primarily upon Foucault and New literacy studies. The study analysed the interplay between potential learning potential, which in this case was a rather open field because teachers had to actively design the world for their students, and actualized learning potential. The virtual $3 \mathrm{D}$-world in this study, which for the students presented itself as an example of didactical learning material set up by the teacher, holds the potential to work with a broad definition of literacy; for example, not solely as an individual activity or just decoding but also as a critical meaning-making practice that mirrored students' everyday literacy practices. However, the teachers, who in a Foucauldian perspective were subjected to social control through curriculum and legislation, gravitated towards officially legitimate literacy-practices and routines (individual tasks, pair-work, etc.). It follows that this study interpreted teachers' perceptions and adaptations as a result of contextual and systemic ties. Hence, this study is also placed under the theme Context matters in the study of use in our synthesis. The author concluded that technology in itself is not sufficient to transform practice.

Erixon (2014) found that a relativization takes place when schools and teaching are remediated by the use of other modal and multimodal resources than the traditional textbook, such as images and multimodal texts from the Internet. Erixon's approach was qualitative in this ethnographic study using classroom observations and interviews as research methods. In 
addition to other findings, the study reported positive student attitudes towards the use of other modes and multimodal resources and that the use of technology fostered students' cooperation.

In Flanagan and Shoffer (2013) the experiences of two teachers, one novice and one experienced, were examined to understand how they considered technology in planning, how they used technology, and how their beliefs about technology influenced their use of technology. The research design was qualitative and the methods used were interviews and classroom observations. Both teachers believed that the use of technology had value in instruction and both experienced similar challenges in integrating it. However, where the novice teacher perceived technology as playing a primary role and adopted a technology-centred approach to teaching, the experienced teacher perceived technology as having a secondary role and only integrated technology when there were didactic gains in doing so.

Hanghøj, Hautopp, Jessen, and Christoffersen (2014) used classroom observations in two schools (five classes) to understand how using educational scenarios for teaching with the computer game Minecraft was a socially negotiated translation between various knowledge practices. The focus was both on teachers and students. As in Merchant (2010) the learning resource presented a rather open world scenario that held the potential for both teacher and student to actively (re)design learning. In one of the two schools, the teachers used minimal framing and redesign while teachers at the other school put in considerable effort to design a storyline for students' activities. The authors concluded that in order to make the game scenario relevant in the L1 and schooling domains and obtain a constructive translation from students' everyday domain, teachers had to take responsibility for and actively design for learning.

Kitson's (2011) single-case study also used classroom observations and interviews to explore how an L1 teacher used a learning object to teach about multimodal reading, and how the teacher responded to using multimodal texts and an interactive whiteboard in teaching. This was not an intervention study; the researcher studied the teacher's agenda to use interactive whiteboard and multimodal resources in her practice and her perspective on challenges and benefits. The case study mainly showed the challenges and deficiencies of the teacher in supporting key processes (based on established theory) that could promote student reading skills vis-à-vis hypertexts. The author concluded 
that both the learning object and interactive whiteboards held potential for disrupting learning if teachers could adapt to the new textual formats (hypertext and multimodality) and transform their pedagogy, notion of texts and readers.

Eilam and Poyas (2012) investigated teachers' response to the introduction of literary text-visual art juxtapositions in literature textbooks, teachers' ideas concerning their potential contribution to the teaching of literature, and their related pedagogical reasoning. The study design was qualitative and the methodological approach phenomenological. Teachers' response and reasoning were explored through deep interviews and analysed inductively, that is, categories were formed through the explorative analysis. Through this design, teachers' cognitive operation processes were described, and the researchers found that teachers, when confronted with different types of literary text-visual art juxtapositions using different types of literary texts and images, tended to actualize their previous knowledge about the literary text and build increasingly abstract interpretations of the juxtapositions.

McElvany, Schroeder, Baumert, Schnotz, Horz, and Ullrich (2012) showed that teachers of geography, biology and German L1 were not sufficiently able to diagnose the cognitive demands that text-picture integration in learning materials put on students and did not sufficiently compensate for demanding learning resources in their instruction. Methods used were surveys for teachers about their practices vis-à-vis text-picture combinations and tests for determining outcomes on student level. It was found that differences observed between teachers in pedagogical beliefs and motivation had important consequences for both the quantity and quality of instruction using both text and pictures.

\section{Concluding Remarks on Theme 1}

The six studies grouped under the theme Agents using (and negotiating, perceiving, socially constructing) learning resources take a close look at actors in the classroom context, to explore subjective and social phenomena either as ethnographic studies or in interventions with minimal prescriptions for teacher and student use. 
Figure 4.

The relation between the three main

perspectives on studying learning resources in

this group of articles.
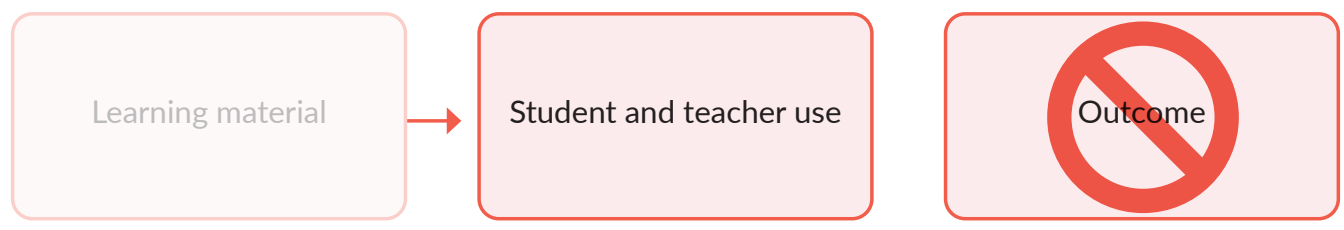

Figure 4 illustrates that these studies are only minimally focused on the design and content of the learning materials and not on outcome - except when outcome as behavioural patterns is interpreted as a sign of how actors perceive, make meaning, etc. These qualitative close-up studies have very minimal design analysis (with Kitson (2011) as an exception). In these studies, the learning material is a backdrop for analysing and understanding complex subjective or cognitive phenomena. The L1 subject tends to fade into the background while broader theoretical constructs are brought to the forefront (again with Kitson (2011) as an exception). Furthermore, in these studies, the learning material can become a more or less arbitrary example of broader categories or theoretical constructs, for example multimodal texts, translations between domains, literacy or technology use. Additionally, Merchant (2010), Hanghøj et al. (2014) and Kitson (2011) were rather normative by imposing more or less broad but preconceived and idealized notions of the L1 subject or teaching to the situations they observed.

\section{Theme 2: Use as Outcome}

In this group of studies, students' use and behaviour are studied as the outcomes of a given intervention. Hence, the common research question in these studies is: Can the use of a specific learning resource lead to certain desired student behaviours? Studies grouped under this theme are studies \#7 and \#12.

In Gissel (2015) a didactic, digital learning material for scaffolding 2nd graders' decoding and reading comprehension was formatively evaluated and redesigned in a design based research study. The author used screen recordings to observe whether students used the learning material as intended, that is, in accordance with a theory based intended learning trajectory, and what redesigns could lead to more optimal patterns of use. These 
formative evaluations were repeated as part of iterative design cycles. The design process reported in the study was part of a larger study that concluded with a randomized controlled trial, and the author stated that the formative evaluation only intended to examine whether students used the material as intended and that this part of the study could not determine effects.

Lorenz, Green, and Brown (2009) examined whether the use of a multimodal, didactic tool could support students in organizing their thoughts and ideas in the pre-writing phase. The researchers observed student interaction, dialogue, and motivation as expressed in concentration and amount of work done, and conducted interviews with the students (supplemented by analyses of the students' products). This small-scale study reached the careful conclusion that there were mixed results, but that "using computing tools to teaching prewriting skills does no harm" (Lorenz et al., 2009, p. 127).

\section{Concluding Remarks on Theme 2}

\section{Figure 5.}

Studies treating use as outcome show a keen interest in the design of the learning materials, but do not estimate effect sizes, for example, on measures of learning outcome.
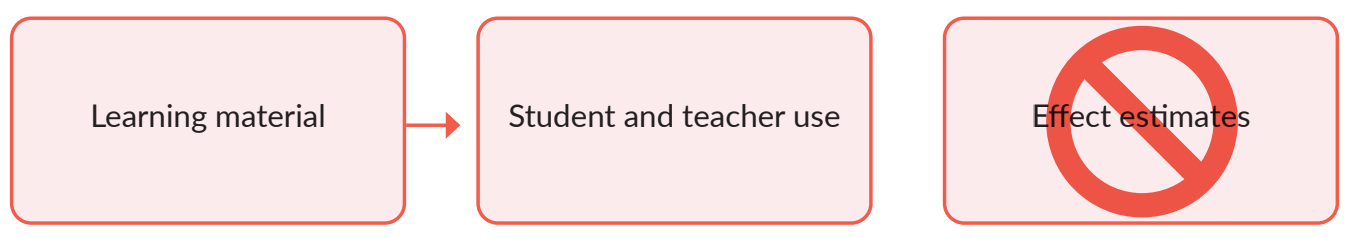

These two studies are interested in use as outcome as an interaction between learning materials (design and content) and users. When use is studied as an outcome, researchers are looking at observable signs that students learn more or better, but in the aforementioned studies without either attempting to or being able to conclude that they in fact do so.

\section{Theme 3: Context Matters in the Study of Use}

Under this heading, two articles were included: \#1 and \#14. These studies showed that a wider context than the classroom must be 
taken into account to understand what influences or determines the use of learning materials.

Burkhauser and Lesaux (2007) investigated how the context (curriculum, legislation, ranking systems etc.) influenced teachers' adaptation of learning materials. The study examined which adaptations teachers of different experience levels performed and also what explained these differences. Furthermore, the authors investigated whether teachers felt that they were free to adapt curricular materials to student needs and instructional goals. The context of the study was a US district where a school performance measurement system was being used to publicly rank schools' academic performance and growth. The learning material in the study was a set of theory-based curriculum materials designed to support academic language instruction. The material had a very detailed lesson-to-lesson teachers' guide with, for example, model scripts of each lesson and examples of what to say in class. The research design was qualitative using teacher interviews, classroom observations by raters that recorded teachers' degree of enactment of critical components in the learning material, teaching quality, and adaptations made by the teacher supplemented by videotaping.

It was found that the context did in fact have a great impact on teacher adaptation, especially regarding unexperienced teachers:

99

This study suggests that many teachers are likely reading and evaluating curriculum materials through a lens imposed on them by the broader policy environments in which they are embedded (e.g. district or state standards). (Burkhauser \& Lesaux, 2007, p. 307)

In Merchant (2010) the context was also seen as controlling teachers' actions. The author's theoretical foundation was the Foucauldian theory of power and dominance. However, in this study the context was not fully elaborated and was not analysed. Rather, it was assumed that context influences actors through homogenization and regulation.

\section{Concluding Remarks on Theme 3}

Studies investigating a broader context surrounding the use of learning materials in school show that multiple factors must be 
taken into consideration when studying learning materials in use. These multiple factors can affect choices, which may also be influenced by unknown factors out of the control of the school and teachers. The studies remind researchers to be aware of these factors.

Figure 6.

A wider context must be taken into account when studying student and teacher use of learning materials.

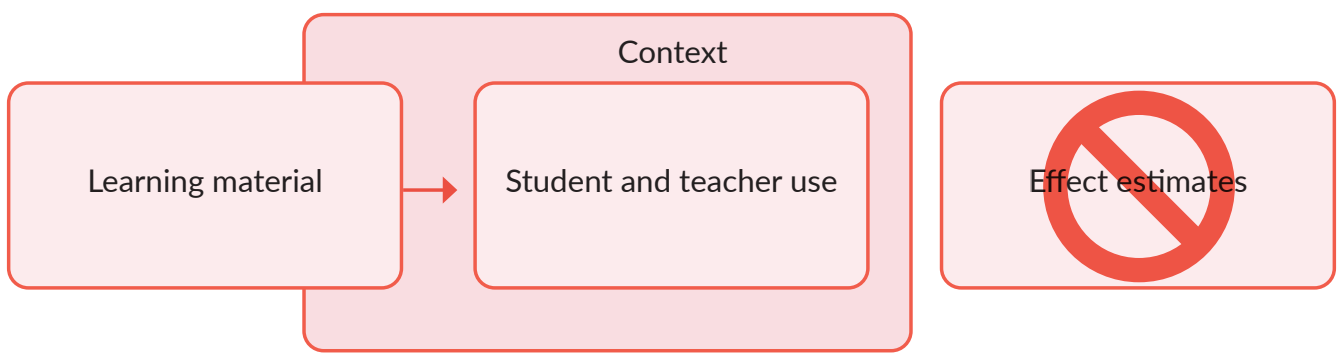

\section{Theme 4: The Study of Use has Implications for Design of Learning Materials}

Under this theme, the study of use either has implications for future design of learning materials, or teacher and students' patterns of use are studied as part of a design process to strengthen the design of the learning material. Hence, the insights gained from studying use feed back to the learning material in different ways (Figure 7). Studies included in this theme are studies \#7, \#8, $\# 13, \# 16$ and $\# 18$.

Grossman and Thompson (2008) used qualitative methods (observation and interviews) in a longitudinal research design to explore how newly educated English teachers perceived and used learning materials, how their use of materials changed with gained experience, as well as the opportunities these teachers had to learn from their materials. Hence, the study both focused on design and use of learning materials. The researchers found that teachers used curriculum materials rather uncritically in the beginning of their teaching career, which was ascribed to a lack of training in critically analysing and evaluating learning materials. However, as teachers became more experienced, they begin to alter the materials and adapt the materials to their spe- 
cific classroom contexts and needs. Additionally, the study found that the teachers were very much influenced by the approaches to teaching they encountered in the materials used in this formative stage of their careers, and that they used these approaches in the future. Two consequences can be drawn from the results of this study:

- The quality of materials teachers encounter early on after becoming licensed teachers is highly important. The authors suggest that materials must not only answer the didactic question of what (content) but also how (didactical methods).

- In addition, the study could suggest that the concreteness that will be found in learning materials adds something valuable to teachers' training that greatly influences them.

McElvany et al. (2012) showed that teachers of geography, biology and German L1 were not sufficiently able to diagnose the cognitive demands that text-picture integration in learning materials put on students and, hence, to compensate for demanding learning resources in their teaching. Methods used were surveys for teachers about their practices, vis-à-vis text-picture combinations and tests for determining outcomes on student level. An implication of this is, that raising the quality of the learning resources and minimizing unwanted cognitive demands is a necessity.

In Renita (2008) the learning material "Accelerated Reader", which enjoys widespread use in the US, tests students to determine their individual reading level. The learning material refers to a range of printed books of literature that students read; they subsequently answer multiple choice questions about the books to receive a reward of some sort (each school decides how to reward students). Through surveys with students and their parents, the author determined that both students and parents referred to goals, tests and extrinsic motivation through doing well in the tests instead of the children's enjoyment with books or personal development. Thus, the study indicated that students reading the books driven by extrinsic motivation, did not meet literature in a dialogic community and did not have the opportunity to reflect on the books that they had read. Instead, students focused on reading many books and answering the multiple choice quizzes correctly. Consequently, the author 
believed that students should be working with interpretations of fiction instead of just reading instrumentally using the books. In the current study, the design of the learning material is seen as determining the actualized design for learning and shapes students' perceptions of the reading activity. Hence, the author's criticism is directed at the designers of the learning material, not the parents, teachers or students.

In Gissel (2015) an iterative design process was carried out to optimize a prototype of learning material for reading instruction in 2nd grade through screen recordings of student interaction with the learning material. The learning material was redesigned in an attempt to make different students use the learning material as intended. Intended use in this study was different for students depending on their reading skills. However, each category of students was observed to determine whether they used the material in the way that was the most optimal according to a theory-based programme describing an intended learning trajectory. Hence, the study of student use had immediate consequences for design of the learning material in this design based study.

Warren, Stein, Dondlinger, and Barab (2009) also reported on a design process. The article described which elements of the interactive multi-user 3D learning environment, "Anytown", worked for students and which do not. The authors formulated future design principles for similar learning materials, for example "write a compelling narrative" and "develop interesting characters" (Warren et al., 2009, pp. 316-317). The approach was qualitative, using field notes, interviews and video recordings.

\section{Concluding Remarks on Theme 4}

Relatively many studies focus on the use of learning materials with the intention of redesigning or criticizing them. The purpose of this focus is to learn about the materials as they are used and thereby point to possible optimizations of designs to create better and more effective learning materials. For some studies, the focus is to optimize or improve the learning materials. Focus can also be on pointing to the influence that learning materials can have on teaching and learning, and thereby highlighting the importance of high-quality learning materials. 
Figure 7.

Use is studied to inform or guide the design of learning materials.
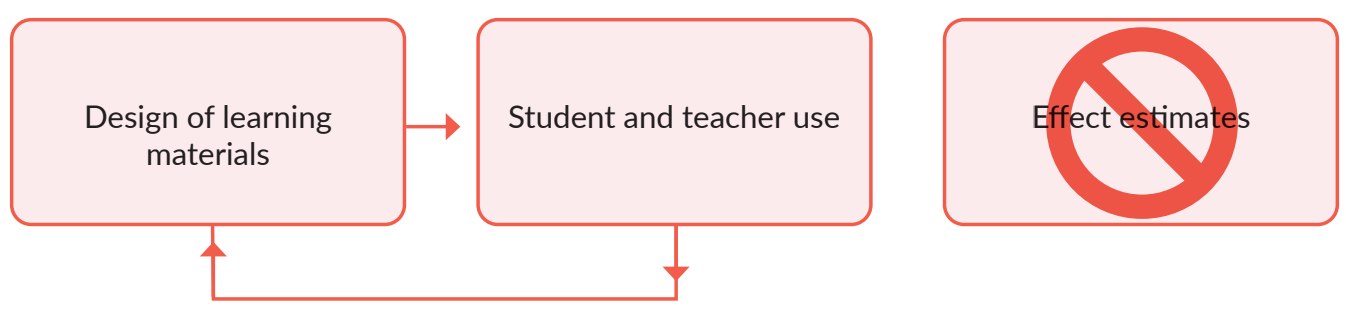

\section{Theme 5: The Study of Use has Implications for Determining the Outcome of Learning Materials}

In this review, we excluded many studies that measure the effect or outcome of learning material unless they also studied use of the learning resource, for example, by studying variations in patterns of use that may explain the measures of outcome. Our focus on use, however, has uncovered some interesting and innovative approaches to supplement the knowledge gained in randomized controlled trials (RCT) and mappings of experienced outcomes. Three studies in our review bring nuances to measuring outcome: \#4, \#15, and \#17.

To understand the importance of the study carried out by Savage, Erten, Abrami, Hipps, Comaskey, and van Lierop (2010), we must first understand the logic behind traditional RCT studies. In RCTs measuring effects of learning materials, efforts are made to control implementation, that is, how the learning material is used, so that optimal and uniform use of the learning material is what is tested (Figure 8). This is termed fidelity of intervention. Hence, teacher adaptation is considered a confounder that must be minimized. 
Figure 8.

In RCTs, the effect estimates of learning

material are determined as directly as

possible. Teacher and student adaptation,

which will be heterogeneous practices, are

considered confounders and are minimized

through strict guidelines for implementation.

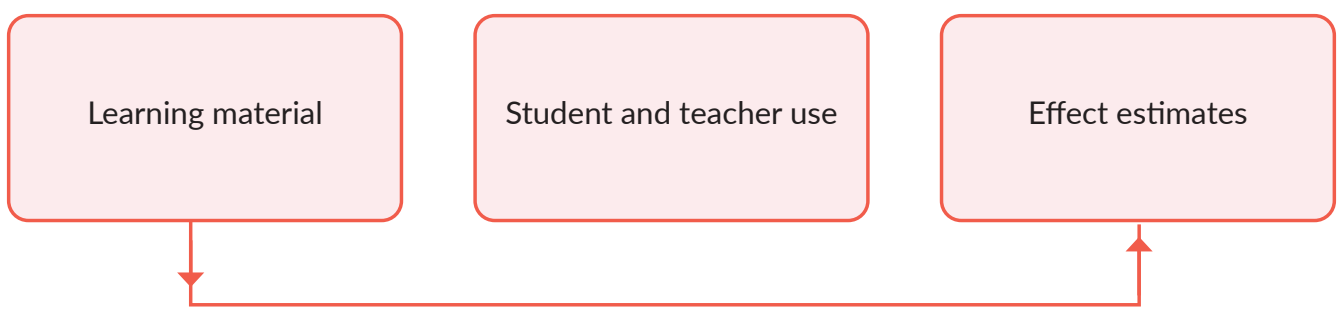

The learning material, in this view, is conceived as a transmitter of learning that must be operated properly by the teacher. Steps taken to optimize and align implementation typically include using handpicked teachers that have received extensive training in using the material, having research staff deliver the intervention, observing classrooms to monitor implementation, and making the intervention take place outside regular class hours in extra lessons.

In Savage et al. (2010) teachers' adaptations styles (use) towards technology were taken as a variable in the measuring of effects estimates. The study used a quasi-experimental research design to estimate the effect on measures of student literacy from using the didactic learning material ABRACADACABRA, which has previously been established as being effective. Savage et al. (2010) conducted their trial as a real world field experiment, that is, with students' regular teachers, and studied how effects on student level varied with the style of teacher technology integration (entry, adoption, and adaptation). It was found, that there were significant differences in effects across the different technology adaptation styles of teachers. Hence, adaptation was found to be $60 \%$ more efficient than adoption. The result is interesting from the standpoint of teachers' use of digital technology, as well as because of the potential consequences of RCTs measuring the impact of learning resources. When teachers deliver the intervention, teachers' didactic competence level is an important source of variation, which is very likely to mirror the actual outcomes in classrooms. This, in turn, means that trials that have 
optimal conditions of experimental control over variables (for example, by replacing regular teachers with university-based researchers) could exaggerate effect sizes.

In Fälth (2013), a mixed-methods research design was used to not only measure the effects of but also to customize and thereby enhance the impact of interventions using training programs for promoting struggling readers' reading development. An RTI (response to intervention) approach was used to individually adapt the interventions to students' needs. The idea behind RTI was to optimize an intervention by studying how students responded to the intervention (both by measuring effects and studying patterns of use) and then tailoring the intervention to suit the needs of students who did not respond as hoped in new tiers of intervention (Berkeley, Bender, Gregg, Peaster, \& Saunders, 2009; Vaughn \& Fuchs, 2003). Hence, the method used knowledge about actualized and realized potential to guide further interventions. Fälth (2013) found that students who received a combination of phonological and comprehension training outperformed the controls on tests measuring word decoding, phonological ability, and reading comprehension.

Moran (2018) used a mixed methods design to shed light on the impact of flipping an Liclassroom on engagement of students by comparing it to a traditional classroom. In flipped learning, students are presented with knowledge outside of the classroom, for example in a video presentation, and apply the knowledge in the classroom supervised by the teacher. Interestingly, Moran conducted a follow-up case study to the survey-study to determine outcomes. In the follow-up study, case-interviews were used to elaborate on the findings in the quantitative part of the study. Moran found that inner and outer motivation was lower in the flipped design, that strategies of organization were poorer, but that effort regulation was unchanged between conditions. However, the flipped design had positive effects for the female students. The case study showed great variation in students' evaluation of the motivational potential of the flipped design and confirmed and elaborated the mixed findings in the quantitative part of the study.

\section{Concluding Remarks on Theme 5}

These three studies show that the study of use of learning resources (the actualized learning potential) has relevance for the 
validity of studies mapping outcomes and RCT studies regarding measuring effects of the use of learning materials. These three studies measure outcome, but include patterns of use or deeper understandings of students' perception as a variable to explain results or to strengthen the interventions. Hence, these studies inform the future design of learning resources or interventions and have higher degrees of ecological validity than, for example, traditional RCT-studies.

\section{Figure 9.}

The study of use of learning materials is an important element in studies mapping outcomes or measuring effects.

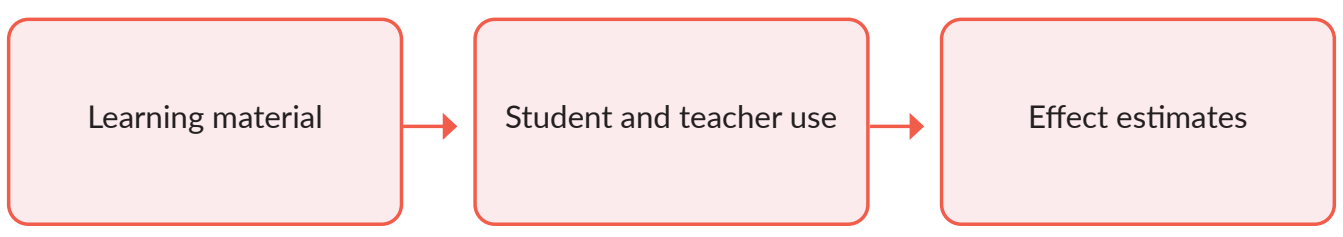

\section{Theme 6: Mapping Use to Monitor Implementation vs. Mapping Use to Give Teachers a Voice}

Mappings of use of learning materials provide an overview by describing patterns of use. Two studies share this purpose: \#6 and \#11. However, there is an important difference in the motivations for providing these mappings.

Gallagher, Arshan, and Woodworth (2016) conducted a cluster-randomized RCT study that measured the effects of the College-Ready Writing Project on students' argument writing. Since this was an RCT study, the fidelity of implementation was monitored. However, the researchers also analysed the data gathered on use in the classrooms to understand how the instructional materials impacted teachers' practice. An important finding was that for an intervention such as this, it was not sufficient to educate teachers in an approach that they had to translate into practice. To ensure that teachers would or were able to conduct the intended approach, they had to be directed towards quality instructional materials that supported the intervention.

Lenski, Larson, McElhone, Davis, Lauritzen, Villagómez, Yeigh, Landon-Hays, LeJeune, and Scales (2006) used surveys and interviews to map how teachers perceived and evaluated differ- 
ent learning materials. The study asked which materials teachers used to teach reading and which patterns emerged across grade levels and different types of schools. Teachers were also asked which approaches they used to teach reading and whether they primarily used packaged programs (didactic learning materials). Furthermore, teachers were asked which materials they would choose, if given the choice. It was found that K-6 teachers primarily used packaged programs, while grade 7-12 teachers primarily used semantic learning resources, that is, fictional texts and other resources that they didacticised themselves. One interesting finding was that teachers said that packaged programs could result in "reduced opportunities for students to engage in their practices" (Lenski et al., 2006, pp. 255-256). Teachers desired to exercise their professional judgement to make decisions about learning materials.

\section{Conclusion, Discussion, and Perspectives}

As a point of departure, we established an analytical framework for the study of learning materials in a realistic context comprising three perspectives: the materials themselves, the use by students and teachers, and the outcomes of the use.

As can be seen, the research into the actual use of learning materials in L1 is scarce, since only eighteen studies were identified. This suggests that it may be difficult to draw more generalized conclusions or formulate general hypotheses about the use of learning materials in L1, either from the perspective of the teacher, the student or the learning material itself.

We find that the majority of studies about use of learning materials focus solely on teachers or on the relationship and interplay between the teacher/students and learning materials. This focus is in line with theory about the importance of learning materials in classroom instruction, which describes the teacher as the most essential party in this set-up. When studies focus solely on students they most often concentrate on the outcome.

Of the eighteen included studies, seven of them examine the relationship between the learning material and the parties involved (the teachers and the students): ( $\# 2, \# 3, \# 5, \# 9, \# 10, \# 13$, and \#14). In these kinds of studies, the L1 subject generally tends to be pushed into the background in favour of general pedagogical or subject specific topics, thus using the learning material as a starting point for discussing theoretical constructs. These 
studies do bring new insight into the subjective and complex phenomena of learning material use from the perspective of students and teachers, but tend to lose sight of the learning materials themselves. Although studying the use of learning materials from the perspective of the users (teachers and students) is very important in practice, we think that the understanding of the designed or intended learning outcome for the learning material is an important prerequisite for understanding what occurs in the classroom and why. We were hoping to find more studies that could add to the understanding and theory of teachers' adaptations and students' use of didactic learning materials. We view this as a necessary research agenda for researchers studying education and learning.

In continuation of this theme, two studies focused on the broader context of the learning material use (\#1 and \#14). These studies show that besides the learning material, multiple factors are at play in a classroom. These are factors that can influence the outcome and use of the learning materials and may also be factors that teachers cannot control or influence themselves. One study (\#14) showed that these factors are often implicit, thus playing an important role without even being discussed. These are valuable results that should be investigated more intensely since context seems to play a more important role than one might assume. It points to the value of studying contextual factors, such as curriculum, ranking regimes, public discussion about the schooling system, in relation to investigating learning materials in use.

Only two studies considered the investigation of the actual outcomes of using specific learning materials (\#7 and \#12). Thus, there is a lack of studies investigating whether learning materials actually make students reach the goals that have been set for the specific learning material. If we believe that learning materials play an important role for the content taught as well as the results achieved, this is a problem for research addressing the use of learning materials since outcomes should be taken into consideration when evaluating learning materials.

In relation to this, two other studies focused on the use of learning materials and the implications for predicting the outcomes (\#4, and \#15). These studies supplied the studying of outcomes by including in-depth studies of use and were thus able to discuss the relation between use and outcome. As such, the role of the learning material was recognized, thus avoiding over- 
looking the learning materials' influence on teaching and learning. These are important contributions to the study of the use of learning materials combined with studies of outcome. Since only two studies focus on this, more studies should be conducted in this area.

Another theme is the study of learning materials in relation to redesigning or improving them. Five studies fall into this category and this shows that this is a more well-researched area (\#7, $\# 8, \# 13, \# 16$ and \#18). Their main focus was to either criticize or improve the learning materials and as such the aim was to ensure better and more effective learning materials. These kinds of studies are important for the study of learning materials in use since they help develop both the materials and the research around them and should, ideally, support the development of better learning materials for both students and teachers. Additionally, these kinds of studies add to the knowledge of learning materials and their content and use in practice.

Finally, two studies considered learning materials in a broader context outside of these five themes to monitor the implementation or give teachers a voice (\#6 and \#11). One study that maps teachers' perceptions and evaluations of materials for reading (\#11) provided valuable insights into how teachers actually taught using didactic learning materials and the choices they would have liked to have made if they had been given the opportunity.

As can be seen, most studies are conducted as qualitative studies on relatively small groups. This enables the study of the theme in focus in depth but at the same time makes it difficult to generate more general hypotheses about the use of learning materials. Clearly, there is a lack of research that can contribute to this.

Furthermore, most of the studies focus on one or maybe two of the elements in the learning material use-model (Figure 3): either the subjects' understanding or reflections of the materials or the outcome, often without considering the use in connection with the outcome. This will often be the implication of smallscale studies, since they must focus their investigations narrowly, but we see a need for more studies including both the study of use and analysis of the learning materials, since we view these as being intertwined.

Following the model of the three perspectives on didactic learning materials in use (Figure 3), all three perspectives are of 
equal importance, and they should be considered intertwined. As can be seen, research into these perspectives and their interdependences is rare, since most studies focus on either one or two of the three perspectives and rarely on their interdependence.

Therefore, we will propose a research agenda for moving the field of research in the use of learning materials forward. Studies should ideally focus on both:

- Analysing the potential potential of the learning materials that are used.

- Providing an in-depth understanding of the use of learning materials by observing their use in actual classroom contexts.

— Gaining insights into subjects' perspectives on use by interviewing teachers and students.

- Researching if and how the didactic goals are actually reached.

\section{References}

\section{Included Articles}

Burkhauser, M. A., \& Lesaux, N. K. (2007). Exercising a bounded autonomy: Novice and experienced teachers' adaptions to curriculum materials in an age of accountability. Journal of Curriculum Studies, 49(3), 291-312. https:// doi.org/10.1080/00220272.2015.1088065

Eilam, B., \& Poyas, Y. (2012). Teachers' interpretations of texts-image juxtapositions in textbooks: From the concrete to the abstract. Journal of Curriculum Studies, 44(2), 265-297.

Erixon, P. (2014). On the remediation, relativisation and reflexivity of mother tongue education. Educational Inquiry, 5(2), 171-194. Retrieved from https://doi.org/10.34.02/edui.v5.23184

Fälth, L. (2013). The use of interventions for promoting reading development among struggling readers (Doctoral dissertation, No 123/2012, Linnaeus University, Växjö, Sweden). Retrieved from https://www.spsm.se/ globalassets/funktionsnedsattning/avhandlingar/the-use-of-interventionsfor-promoting-reading-development-among-struggling-readers-falt-linda. pdf

Flanagan, S., \& Shoffer, M. (2013). Teaching with(out) technology: Secondary English teachers and classroom technology use. Contemporary Issues in Technology and Teacher Education, 13(3), 242-261.

Gallagher, H. A., Arshan, N., \& Woodworth, K. (2016). Impact evaluation of the National Writing Project's College-Ready Writing Project in high poverty rural districts. Paper presentation at The SREE Spring 2016 conference, Washington, DC.

Gissel, S. T. (2015). Scaffoldings students' independent decoding of unfamiliar text with prototype of an ebook-feature. Journal of Information Technology Education: Research, 14, 439-470. Retrieved from http://www.jite.org/documents/Vol14/JITEv14ResearchP439-470Gissel2075. pdf 
Grossman, P., \& Thompson, C. (2008). Learning from curriculum materials: Scaffolds for new teachers? Teaching and Teacher Education, 24, 2014-2026. https://doi.org/10.1016/j.tate.2008.05.002

Hanghøj, T., Hautopp, H., Jessen, C., \& Christoffersen, R. D. (2014). Redesigning and reframing educational scenarios for Minecraft within mother tongue education. In C. Busch (Ed.), ECGBL 2014. Proceedings of the 8th European Conference on Game-Based Learning. University of Applied Sciences HTW Berlin Germany 9-10 October 2014, 182-19o. Reading: Academic Conferences and Publishing International.

Kitson, L. (2011). Reconceptualising understandings of texts, readers and contexts: One English teacher's response to using multimodal texts and interactive whiteboards. English in Australia, 46(3), 76-86.

Lenski, S., Larson, M., McElhone, D., Davis, D. S., Lauritzen, C., Villagómez, Yeigh, M., Landon-Hays, M., LeJeune, M., \& Scales, W. D. (2006). What teachers want: A state-wide survey of reading and English language arts teachers' instructional materials, preferences, and practices. Literacy Research and Instruction, 55(3), 237-261. https://doi.org/10.1080/19388071.2016.1156202

Lorenz, B., Green, T., \& Brown, A. (2009). Using multimedia graphic organizer software in the prewriting activities of primary school students: What are the benefits? Computers in the Schools, 26(2), 115-129. https://doi.org/10.1080/07380560902906054

McElvany, N., Schroeder, S., Baumert, J., Schnotz, W., Horz, H., \& Ullrich, M. (2012). Cognitively demanding learning materials with texts and instructional pictures: Teachers' diagnostic skills, pedagogical beliefs and motivation. European Journal of Psychology of Education, 27(3), 4.03-4,20.

Merchant, H. H. (2010). 3D virtual worlds as environments for literacy learning. Educational Research, 52(2), 137-150.

Moran, C. (2018). “Just don't bore us to death": Seventh graders' perceptions of flipping a technology-mediated English language arts unit. Middle Grades Review, 4(1), 1-18.

Mullis, I. V., Martin, M. O., Foy, P., \& Arora, A. (2012). TIMSS 2011 international results in mathematics. Chestnut Hill, MA: TIMSS \& PIRLS International Study Center.

Renita, S. (2008). Really reading: What does Accelerated Reader teach adults and children? Language Arts, 85(3), 202-211.

Savage, R. S., Erten, O., Abrami, P., Hipps, G., Comaskey, E., \& van Lierop, D. (2010). ABRACADABRA in the hands of teachers: The effectiveness of a webbased literacy intervention in grade 1 language arts programs. Computers $\mathcal{E}$ Education, 55, 911-922.

Warren, S. J., Stein, R. A., Dondlinger, M. J., \& Barab, S. A. (2009). A look inside a MUVE design process: blending instructional design and game principles to target writing skills. Journal of Educational Computing Research, 4O(3), 295-321. https://doi.org/10.2190\%2FEC.40.3.c

\section{Other References}

Berkeley, S., Bender, W. N., Gregg Peaster, L., \& Saunders, L. (2009). Implementation of response to intervention: A snapshot of progress. Journal of Learning Disabilities, 42(1), 85-95.

Bryman, A. (2012). Social Research Methods. New York: Oxford University Press. 
Bundsgaard, J., \& Hansen, T. I. (2011). Holistic evaluations of learning materials. In Rodríguez, J. R., Horsley, M., \& Knudsen, S. V. (Eds.), Local, National and Transnational Identities in Textbooks and Educational Media: Ten International Conference on Research on Textbooks and Educational Media September 2009 Santiago de Compostela - Spain, 502-520. Santiago: IARTEM.

Gilje, Ø., Ingulfsen, L., Dolonen, J. A., Furberg, A., Rasmusse, I., Klug, A., Knain, E., Mørch, A., Naalsund, M., \& Skarpaas, K. G. (2016). Med ARKEAPP. Bruk av loeremidler og ressurser for loering på tvers av arbeidsformer [With paper \& App. Use of teaching and learning materials and resources for learning across working methods]. Oslo: Universitetet i Oslo. Retrieved January 11th, 2019. Retrieved from http://www.uv.uio.no/iped/forskning/ prosjekter/ark-app/arkapp_syntese_endelig_til_trykk.pdf.

Gilje, Ø. (2016). På jakt etter ark og app i fire fag i det nye norske læremiddellandskapet. Learning Tech, 1(1), 36-61. https://doi.org/10.7146/ lt.v1i1.107619

Gough, D., Thomas, J., \& Oliver, S. (2012). Clarifying differences between review designs and methods. Systematic reviews, 1(1), 1-9.

Hansen, J. J. (2006). Mellem design og didaktik: Om digitale loeremidler i skolen. (Doctoral dissertation, SDU, Faculty of Humanities, Institute for Design and Communication).

Hansen, T. I., \& Gissel, S. T. (2017). Quality of learning materials. IARTEM e-Journal, $9(1), 122-141$.

Houang, R. T., \& Schmidt, W. H. (2008). TIMSS international curriculum analysis and measuring educational opportunities. In 3rd IEA International Research Conference TIMSS.

Knudsen, S. V. (Ed.) (2011). Internasjonal forskning på lceremidler - en kunnskapsstatus. Høgskolen i Vestfold. Retrieved from https://www.udir.no/ Upload/Rapporter/2012/laremidler_hive.pdf

Ongstad, S. (2012). Trender i internasjonal morsmålsdidaktisk forskning? Norsk Pedagogisk Tidsskrift, 3(96), 172-184.

Schmidt, W. H., McKnight, C. C., Houang, R. T., Wang, H., Wiley, D. E., Cogan, L. S., \& Wolfe, R. G. (2001). Why schools matter. Sansome, CA, USA: JosseyBass.

Schubert, W. H. (n.d.). Intended curriculum. Encyclopedia of Curriculum Studies. Retrieved from https://sk.sagepub.com/reference/ curriculumstudies/n263.xml. DOI: http://dx.doi.org/10.4135/9781412958806. n262

Selander, S., \& Kress, G. R. (2010). Design för lärande: Ett multimodalt perspektiv. Stockholm: Norstedt.

Sigurgeirsson, Ingvar. (1992) The role, use and impact of curriculum materials in intermediate level Icelandic classrooms (Doctoral dissertation, University of Sussex, Brighton).

Sikorová, Z. (2011). The role of textbooks in lower secondary schools in the Czech Republic. IARTEM e-Journal, 4(2), 1-22.

Sikorová, Z., \& Iva Červenková, I. (2014). Styles of textbook use. The New Educational Review, 35, 112-122.

Sosniak, L. A., \& Perlman, C. L. (1990). Secondary education by the book. Journal of Curriculum Studies, 22(5), 427-442. https://doi. org/10.1080/0022027900220502.

Vaughn, S., \& Fuchs, L. S. (2003). Redefining learning disabilities as inadequate response to instruction: The promise and potential problems. Learning Disabilities Research \& Practice, 18(3), 137-146. 
Watt, M. (2015). Research on textbook use in the United States of America. IARTEM e-Journal, 7(2), 48-72.

Wikman, T., \& Horsley, M. (2012). Down and up: Textbook research in Australia and Finland. IARTEM e-Journal, 5(1), 45-53.

Valverde, G. A., Bianchi, L. J., Wolfe, R. G., Schmidt, W. H., \& Houang, R. T. (2002). According to the book: using TIMSS to investigate the translation of policy into practice through the world of textbooks. Dordrecht: Kluwer Academic Publishers.

\section{Appendix 1}

\section{Full Search Strings}

Databases that support partial block search have been searched as block searches to the extent possible given the affordances of the database.

\section{International databases}

Education Resources Information Center (ERIC) EBSCOhost Friday, November 02, 2018 4:54:38 AM

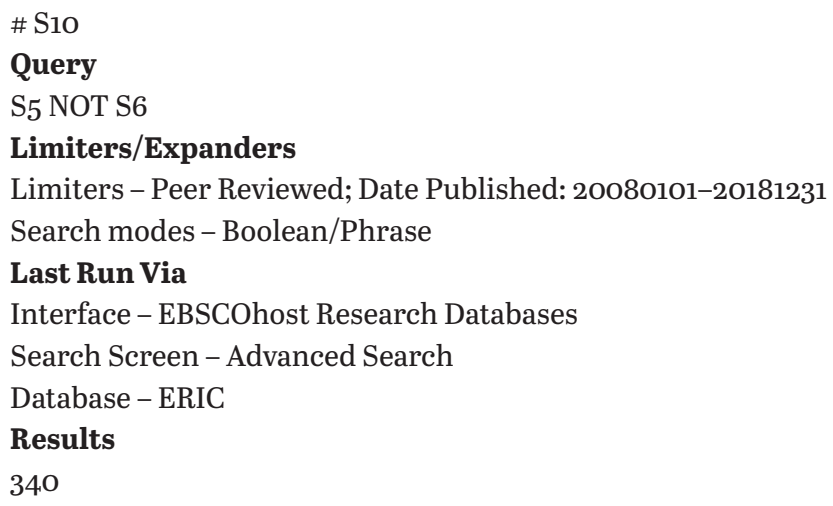


Search modes - Boolean/Phrase

Last Run Via

Interface - EBSCOhost Research Databases

Search Screen - Advanced Search

Database - ERIC

Results

4,314

\# S7

Query

( ( $\mathrm{L} 1 \mathrm{OR}$ "mother tongue” OR "mother tongues" OR "native language” OR "native languages" OR "native language instruction" OR "native language instructions" OR "first language" OR "first languages" OR "primary language" OR "primary languages" OR "english instruction" OR "english instructions" OR "language art” OR "language arts" OR "english language education") ) AND ( ("learning module" OR "learning modules" OR "teaching aid" OR "teaching aids" OR "teaching machine" OR "teaching machines" OR "teacher developed material" OR "teacher developed materials" OR "instructional material" OR "instructional materials" OR "educational material" OR "educational materials" OR "teaching material” OR "teaching materials" OR "learning material” OR "learning materials" OR "curriculum material" OR "curriculum materials" OR "school book" OR "school books" OR textbooks OR "digital textbook" OR "digital textbooks" OR "talking book" OR "talking books" OR "readers (textbooks)" OR "basal reader" OR "basal readers" OR "basal reading” OR "basal reading instruction" OR "basal reading instructions" OR "reading material” OR "reading materials" OR "computers \& literacy" OR "learning tool" OR "learning tools" OR "digital learning tool" OR "digital learning tools" OR "educational media" OR "technology use in education" OR "technology uses in education" OR "computer use in education" OR "computer uses in education" OR "computer assisted instruction" OR "computer assisted instructions" OR "computer assisted language instruction" OR "computer assisted language instructions" OR "computer assisted reading instruction" OR "computer assisted reading instructions OR "reading software" OR "educational technology" OR "educational technologies" OR "audiovisual instruction" OR "audiovisual instructions" OR "audiovisual material” OR "audiovisual materials" OR "multimedia instruction” OR "multimedia instructions” OR "MEDIA programs (Education)" OR "MULTIMEDIA systems in education" OR "PROGRAMMED instruction" OR "PROGRAMMED instructions" OR "Programmed Instructional Material" OR "Programmed Instructional Materials" OR "web based instruction" OR "web based instructions" OR "game based learning" OR "game based teaching" OR "learning game" OR "learning games" OR "e-learning” OR "Text-to-speech" OR "educational text" OR "educational texts" OR "pedagogical text" OR "pedagogical texts") ) AND ( ("elementary school” OR "elementary schools" OR "primary school" OR "primary schools" OR "secondary school” OR "secondary schools" OR "primary education" OR "secondary education" OR "elementary education" OR "elementary secondary education" OR "middle school” OR "middle schools" OR "grade 1" OR "grade 2" OR "grade 3" OR "grade 4" OR "grade 5" OR 
“grade 6" OR "grade 7" OR "grade 8" OR "grade 9") ) ) NOT ( (efl OR "english as a foreign language” OR L2 OR "second language” OR “special education”) )

\section{Limiters/Expanders}

Search modes - Boolean/Phrase

\section{Last Run Via}

Interface - EBSCOhost Research Databases

Search Screen - Advanced Search

Database - ERIC

\section{Results}

5,839

\# S6

Query

(efl OR "english as a foreign language" OR L2 OR "second language" OR "special education")

\section{Limiters/Expanders}

Search modes - Boolean/Phrase

Last Run Via

Interface - EBSCOhost Research Databases

Search Screen - Advanced Search

Database - ERIC

\section{Results}

127,345

\section{\# S5}

Query

( (L1 OR "mother tongue" OR "mother tongues" OR "native language" OR "native languages" OR "native language instruction" OR "native language instructions" OR "first language" OR "first languages" OR "primary language" OR "primary languages" OR "english instruction" OR "english instructions" OR "language art” OR "language arts" OR "english language education”) ) AND ( ("learning module" OR "learning modules" OR "teaching aid" OR "teaching aids" OR "teaching machine" OR "teaching machines" OR "teacher developed material" OR "teacher developed materials" OR "instructional material" OR "instructional materials" OR "educational material" OR "educational materials" OR "teaching material" OR "teaching materials" OR "learning material” OR "learning materials" OR "curriculum material” OR "curriculum materials" OR "school book" OR "school books" OR textbooks OR "digital textbook" OR "digital textbooks" OR "talking book" OR "talking books" OR "readers (textbooks)" OR "basal reader" OR "basal readers" OR "basal reading” OR "basal reading instruction" OR "basal reading instructions" OR "reading material” OR "reading materials" OR "computers \& literacy" OR "learning tool" OR "learning tools" OR "digital learning tool" OR "digital learning tools" OR "educational media" OR "technology use in education" OR "technology uses in education" OR "computer use in education" OR "computer uses in education" OR "computer assisted instruction" OR "computer assisted instructions" OR "computer assisted language instruction" OR "computer assisted language instructions" OR "computer assisted reading instruction" OR "computer assisted reading instructions OR "reading software" OR "educational technology" OR "educational technologies” OR "audiovisual instruction” OR "audiovisual instruc- 
tions" OR "audiovisual material" OR "audiovisual materials" OR "multimedia instruction" OR "multimedia instructions" OR "MEDIA programs (Education)" OR "MULTIMEDIA systems in education" OR "PROGRAMMED instruction" OR "PROGRAMMED instructions" OR "Programmed Instructional Material" OR "Programmed Instructional Materials" OR "web based instruction" OR "web based instructions" OR "game based learning" OR "game based teaching" OR "learning game" OR "learning games" OR "e-learning” OR "Text-to-speech" OR "educational text" OR "educational texts" OR "pedagogical text" OR "pedagogical texts") ) AND ( ("elementary school” OR "elementary schools" OR "primary school" OR "primary schools" OR "secondary school" OR "secondary schools" OR "primary education" OR "secondary education" OR "elementary education" OR "elementary secondary education" OR "middle school" OR "middle schools" OR "grade 1 " OR "grade 2 " OR "grade 3 ” OR "grade 4" OR "grade 5 ” OR "grade 6" OR "grade 7" OR "grade 8" OR "grade 9") )

Limiters/Expanders

Search modes - Boolean/Phrase

Last Run Via

Interface - EBSCOhost Research Databases

Search Screen - Advanced Search

Database - ERIC

Results

5,260

\# S4

Query

S1 AND S2 AND S3

Limiters/Expanders

Search modes - Boolean/Phrase

Last Run Via

Interface - EBSCOhost Research Databases

Search Screen - Advanced Search

Database-ERIC

Results

5,260

\# S3

Query

("elementary school" OR "elementary schools" OR "primary school” OR "primary schools" OR "secondary school” OR "secondary schools" OR "primary education" OR "secondary education" OR "elementary education” OR "elementary secondary education" OR "middle school” OR "middle schools" OR "grade 1" OR "grade 2" OR "grade 3" OR "grade 4" OR "grade 5” OR "grade 6” OR "grade 7" OR "grade 8” OR "grade 9")

Limiters/Expanders

Search modes - Boolean/Phrase 


\section{Last Run Via}

Interface - EBSCOhost Research Databases

Search Screen - Advanced Search

Database - ERIC

Results

573,097

\# S2

Query

("learning module" OR "learning modules" OR "teaching aid" OR "teaching aids" OR "teaching machine" OR "teaching machines" OR "teacher developed material" OR "teacher developed materials" OR "instructional material" OR "instructional materials" OR "educational material" OR "educational materials" OR "teaching material” OR "teaching materials" OR "learning material" OR "learning materials" OR "curriculum material" OR "curriculum materials" OR "school book" OR "school books" OR textbooks OR "digital textbook" OR "digital textbooks" OR "talking book" OR "talking books" OR "readers (textbooks)" OR "basal reader" OR "basal readers" OR "basal reading” OR "basal reading instruction" OR "basal reading instructions" OR "reading material” OR "reading materials" OR "computers \& literacy" OR "learning tool" OR "learning tools" OR "digital learning tool” OR "digital learning tools" OR "educational media" OR "technology use in education" OR "technology uses in education" OR "computer use in education" OR "computer uses in education" OR "computer assisted instruction" OR "computer assisted instructions" OR "computer assisted language instruction" OR "computer assisted language instructions" OR "computer assisted reading instruction" OR "computer assisted reading instructions OR "reading software" OR "educational technology" OR “educational technologies" OR "audiovisual instruction" OR "audiovisual instructions" OR "audiovisual material” OR "audiovisual materials" OR "multimedia instruction" OR "multimedia instructions” OR "MEDIA programs (Education)" OR "MULTIMEDIA systems in education" OR "PROGRAMMED instruction" OR "PROGRAMMED instructions" OR "Programmed Instructional Material" OR "Programmed Instructional Materials" OR "web based instruction" OR "web based instructions" OR "game based learning" OR "game based teaching" OR "learning game" OR "learning games" OR "e-learning" OR "Text-to-speech" OR "educational text" OR "educational texts" OR "pedagogical text" OR "pedagogical texts")

\section{Limiters/Expanders}

Search modes - Boolean/Phrase

Last Run Via

Interface - EBSCOhost Research Databases

Search Screen - Advanced Search

Database - ERIC

Results

167,606 
(L1 OR "mother tongue" OR "mother tongues" OR "native language" OR "native languages" OR "native language instruction" OR "native language instructions" OR "first language" OR "first languages" OR "primary language" OR "primary languages" OR "english instruction" OR "english instructions" OR "language art” OR "language arts" OR "english language education")

\section{Limiters/Expanders}

Search modes - Boolean/Phrase

Last Run Via

Interface - EBSCOhost Research Databases

Search Screen - Advanced Search

Database-ERIC

Results

46,897

Teacher Reference Center (TRC)

Search: Block 1 AND Block 2 AND Block 3, with limits: 57 hits

$\begin{array}{lll}\square \text { S19 S1 AND S2 AND S3 } & \text { Limiters - Published Date: } & \text { 20080101-20181231; Peer Reviewed } \\ & \text { Search modes - Boolean/Phrase }\end{array}$

\section{PsycINFO}

Search: Block 1 AND Block 2 AND Block 3, with limits: 35 hits

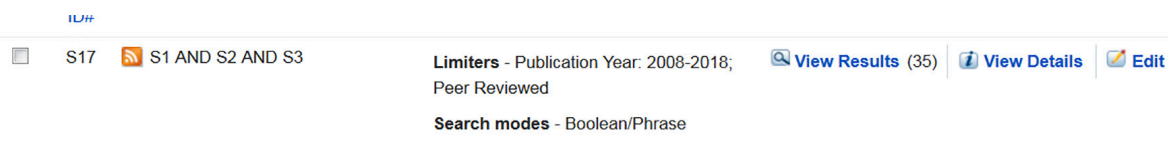

Academic Search Premier

Search: (Block 1 AND Block 2 AND Block 3) NOT Block 4, with limits: 121

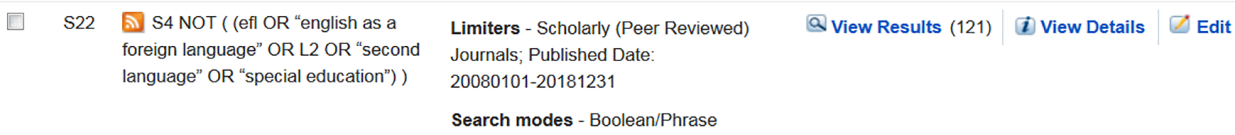




\section{Nordic databases}

\section{Den danske forskningsdatabase}

(Læremidler* OR Læremiddel* OR Læringsressource OR Undervisningsmateriale OR Lærebog OR lærebøger OR (digitale medier) OR Computerspil OR e-læring OR læringsspil OR "Learning material” OR "Learning module" OR "Educational material" OR Textbook OR "digital textbook" OR "digital media" OR "educational media" OR "technology use" OR (Game-based learning) OR (Game-based teaching) OR "e-learning” OR "Learning game" OR "computer-assisted") AND (L1 OR Dansk* OR English OR "Mother tongue” OR Modersmål* OR Sprog* OR Litteraturundervising OR litteraturdidaktik OR Læsning OR skrivning OR Grammatik OR Language OR "Literature teaching” OR Reading OR Writing OR Grammar) AND (skole OR school OR uddannelse OR education OR undervisning OR teaching OR didaktik OR didactics OR læring OR learning OR selektion OR selection OR evaluering OR evaluation OR planlægning OR planning)

Search block 1 AND Block 2 AND Block 3, with limits: 393 hits

Oria.no: 73

\section{Libris}

Libris does not allow searches across publications with our range of limiters. Hence, we had to perform searches for each type of publication (articles/chapters, journal, dissertation) separately.

\section{(Læremidler* OR Læremiddel* OR Læringsressource OR}

Undervisningsmateriale OR Lærebog OR lærebøger OR (digitale medier) OR Computerspil OR e-læring OR læringsspil OR "Learning material" OR "Learning module" OR "Educational material" OR Textbook OR "digital textbook" OR "digital media" OR "educational media” OR "technology use" OR (Game-based learning) OR (Game-based teaching) OR "e-learning” OR "Learning game" OR “computer-assisted") AND (L1 OR Dansk* OR English OR "Mother tongue" OR Modersmål* OR Sprog* OR Litteraturundervising OR litteraturdidaktik OR Læsning OR skrivning OR Grammatik OR Language OR "Literature teaching” OR Reading OR Writing OR Grammar) AND (skole OR school OR uddannelse OR education OR undervisning OR teaching OR didaktik OR didactics OR læring OR learning OR selektion OR selection OR evaluering OR evaluation OR planlægning OR planning)

Search: articles/chapters: 129 hits, journal: 25 hits, dissertation: 131 hits. With limiter: years 2008-2018: 212 hits. After removal of internal duplicates: 192 hits. 


\section{Learning Tech - Tidsskrift for læremidler, didaktik og teknologi}

Udgives af Læremiddel.dk

Learning Tech er et forskningstidsskrift, hvor alle artikler er forskerbedømt i form af dobbeltblindt peer review. Tidsskriftet bringer artikler, der rammer genstandsfeltet mellem læremidler, didaktik og teknologi, og hensigten er at spille en betydelig rolle som platform for den voksende skandinaviske læremiddelforskning.

\section{Redaktion}

Stig Toke Gissel, UCL Erhvervsakademi og Professionshøjskole (ansvarshavende redaktør)

Bettina Buch, Professionshøjskolen Absalon

Hildegunn Juulsgaard Johannesen, University College Syd

Ove Christensen, Professionshøjskolen Absalon

Peter Holmboe, University College Syd

René Boyer Christiansen, Professionshøjskolen Absalon

Thomas R. S. Albrechtsen, University College Syd

\section{Redaktionssekretær}

Trine Ellegaard, UCL Erhvervsakademi og Professionshøjskole

\section{Temaredaktion}

Bettina Buch, Professionshøjskolen Absalon

Stig Toke Gissel, UCL Erhvervsakademi og Professionshøjskole

Stine Reinholdt Hansen, UCL Erhvervsakademi og Professionshøjskole

\section{Design og grafisk tilrettelæggelse}

Trefold - grafisk design og kommunikation

\section{Tryk}

Narayana Press, Gylling

ISSN 2445-7981 (Tryk)

ISSN 2445-6810 (Online)

\section{Rettigheder}

(c) 2020 Læremiddel.dk og forfatterne

\section{Kontakt}

Læremiddel.dk, Niels Bohrs Allé 1,5230 Odense M

www.laeremiddel.dk

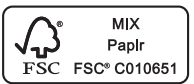

